\title{
4 Constructivist paradigms: implications for strategy-as-practice research
}

\author{
SIMON GRAND, WIDAR VON ARX and JOHANNES \\ RÜEGG-STÜRM
}

\section{Introduction}

The practice turn in strategy research (Johnson, Melin and Whittington 2003; Johnson et al. 2007; Golsorkhi et al. 2010; Vaara and Whittington 2012) implies an explicit reconsideration of paradigmatic premises (Tsoukas and Knudsen 2002; Feldman and Orlikowski 2011; Vaara and Whittington 2012). The strategy-as-practice research programme challenges concepts of strategy that have long been taken for granted, uncovering the complexities of the 'social fabric' of strategy-making (Latour 1996). Furthermore, it undermines the apparently self-evident premises of strategy research and its relation to strategymaking by referring to various constructivist perspectives, theories and methodologies.

Looking at the main contributions to strategy-aspractice research of the last few years, a handful of patterns seem dominant. One can distinguish between three dimensions (Johnson et al. 2007; Orlikowski in this volume). On an empirical level ('phenomenon'), strategy-making is seen as involving multiple construction processes and activities and multiple actors inside and outside the organization, distributed across multiple organizational layers (Johnson, Melin and Whittington 2003; Jarzabkowski and Spee 2009). While strategies and strategy processes are traditionally treated as defined entities, the strategy-as-practice research programme emphasizes their constructedness, and thus their heterogeneity, processuality and fragility. On a theoretical level ('perspectives'), the study of strategy-making requires approaches that provide conceptual cover for this heterogeneous mesh of processes, activities and actors, as well as the fact of their situatedness and embeddedness. It is argued that a focus on the practice of strategy-making therefore implies a discussion of the underlying action theories (Grand and MacLean 2007; Jarzabkowski 2004; Tsoukas and Knudsen 2002) and, specifically, theories of practice (Schatzki, Knorr Cetina and von Savigny 2001). On a philosophical level ('philosophies'), this emphasis on strategymaking as social practice requires a consideration of scientific research itself from the vantage point of practice (Knorr Cetina 2002; Tsoukas 2005). How do scientific research itself and particular research practices contribute to the construction of the field of strategy, both scientifically and organizationally (Knights and Morgan 1991)?

In this chapter, we explore specifically why an interest in strategy practice(s) promotes constructivist perspectives. For this purpose, constructivism is understood as a paradigm (Kuhn 1996; Guba and Lincoln 1994), a set of fundamental assumptions and worldviews underlying most of the theories used by strategy-as-practice researchers. It is our aim to uncover some of the basic premises underlying constructivist epistemologies as well as their potential for advancing the SAP research programme, and strategy research more generally. To focus our discussion, we ask two main questions.

How do constructivist paradigms shape strategyas-practice research? How could constructivist paradigms contribute to the future advancement of the field?

We explore these questions in two steps. First, we introduce three influential, archetypal constructivist 
approaches - the programme of social construction, systemic constructivism, and the empirical programme of constructivism - by exploring their idiosyncrasies and the differences and/or common ground between them. Second, we discuss the impact of constructivist paradigms on research in the strategy-as-practice field. The analysis is structured along four dimensions: (1) the identification of practices, activities and actors as the main constituents of scientific descriptions and explanations in strategy research (addressing ontological issues); (2) the understanding and conceptualization of 'strategy' and 'strategic' (addressing epistemological issues); (3) the conduct of strategy research understood as a construction process (identifying the methodological issues of the programme); and (4) the practical relevance and political aspect of a strategy-as-practice perspective (and, by implication, normative issues).

By doing so, we combine a discussion of the field as it has emerged over recent years with the discussion of prospects for its future development. We conclude this chapter by identifying critical issues that are essential for extending SAP research on the side of constructivist research paradigms.

\section{Constructivist paradigms}

With a wide choice of constructivist perspectives and approaches available (Hacking 1999), we focus on three central, but distinct approaches that represent both the commonalities and the differences in the constructivist research programme. To this end, we discuss the research programme of social construction (Berger and Luckmann 1967; Luckmann 1992), systemic constructivism (Maturana and Varela 1987; Luhmann 1996) and the empirical programme of constructivism (Latour and Woolgar 1986; Knorr Cetina 1981; Latour 2005). These programmes share four major concerns, which are also explicitly addressed in contributions to the strategy-as-practice research programme. By 'concerns', we mean controversial issues that are raised, discussed and addressed explicitly in these approaches, instead of being covered as theoretical and philosophical pre-conceptualizations and thus black-boxed as self-evident and taken for granted (Latour 2005). This implies that we see constructivist paradigms as opportunities for questioning established research paradigms, while introducing alternative paradigmatic orientations.

Concern 1. The constructivist programmes question a concept of 'reality' as something that is 'objectively given', instead focusing on the construction processes implied in the creation, establishment and stabilization of 'reality'. This explains why constructivist perspectives imply ontological considerations, as embedded in (social) practice itself.

Concern 2. Constructivist research programmes specifically study the status of 'knowledge' (Tsoukas 2005), the relation to the 'world' (Goodman 1987) and the process of the scientific generation of knowledge (Knorr Cetina 2002), thus reflecting research as a construction process, which inherently implies epistemological considerations.

Concern 3. Agency in the creation process cannot automatically be associated with particular entities ('individual', 'organization', 'institutional'), but must be studied as distributed among heterogeneous actants (Latour 2005). This makes the methodological consideration of the creative qualities of research essential (Lury and Wakeford 2012).

Concern 4. They challenge the predominance of unquestioned dichotomies in the social sciences, between micro and macro, between subjective and objective or between situated activities and collective practices (Bourdieu and Wacquant 1992), including the recognition of the normative qualities of any such distinction (Thévenot 2006).

Although the three constructivist paradigms discussed in the next section of the chapter share these four concerns, they differ with respect to their basic premises as well as the ways in which they address these concerns (Knorr Cetina 1989; Hacking 1999).

\section{Research programme of social construction}

The research programme of social construction is embedded in a phenomenological reinterpretation of the social sciences (Husserl 1931; Schütz 1932), 
studying 'reality' and 'knowledge' as resulting from social construction processes; reality is always a reality for and by humans. The social construction of reality is seen as ingrained in mundane activities and multiple practices, continuously enacted by the social actors themselves. Thereby, it is important to understand how it is possible for particular 'realities' to be accepted as 'objective', 'given', 'external' or 'natural'. From the vantage point of this research programme, knowledge is understood as resulting from social construction processes, in particular institutionalization, objectivation and legitimization (Berger and Luckmann 1967). These processes are described as leading to the experience of a legitimate backdrop of established knowledge and social order.

Scientific knowledge results from the generation of second-order knowledge, the construction of scientific 'knowledge' on the social construction of 'knowledge' (Schütz 1967 [1932]). Every social phenomenon can be studied as the result of a construction process (Hacking 1999). The starting point for any inquiry in social constructivism is subjective, individual meaning ('Lebenswelt'). The purpose of empirical reconstruction is to shed light on the process of 'objectivation' from subjective meaning to shared understanding and common knowledge. More recently the research programme has turned towards a theory of social action (Luckmann 1992), identifying social action as the primary locus of social meaning in the making. This is a coherent extension of the initial programme, which emphasizes that common-sense knowledge is a meaningful focus of any sociology of knowledge (Knoblauch 2005).

Social action is predominantly shaped by implicit everyday knowledge, which is legitimate and objective in a particular situation or context, but which gains its legitimacy and objectivity through the social construction processes that transcend these situations and contexts (concern 1). Social constructivism thereby refers to anthropological premises concerning the "creation of knowledge; and 'making of meaning' (discussed as implied 'proto-sociology': Eberle 1992) (concern 2). Thereby, the research programme is understood as 'sociology of knowledge' (Knoblauch 2005), with a particular interest in the situated and social construction of knowledge in everyday activities and scientific research (concern 3). Social 'reality' is considered 'objective' and 'subjective' at the same time. Objective reality, although the outcome of social construction, appears to individuals as a given, while subjective reality refers to the continuous making of meaning in everyday social interactions (concern 1).

While this perspective is influential in discussions of constructivist paradigms, it is often cited without a careful consideration for these underlying premises. Furthermore, various difficulties with this perspective have been discussed over time. It has been argued that the application of this perspective can become tautological when 'social' phenomena are seen as resulting from 'social' construction (Latour 2005). It remains difficult to demonstrate in an empirical study that 'something' is socially constructed (Hacking 1999). The approach assumes a collectively shared common understanding of 'reality' and 'knowledge', while its fragility and heterogeneity remain underexplored. Overall, the intuition behind the research programme is a central reference for constructivist epistemologies, but, without a careful consideration for the underlying premises, the simple assertion of 'reality' and 'knowledge' as being constructed becomes trivial.

\section{Systemic constructivism}

In line with this critique, and in order to identify more explicit conceptual foundations, constructivism can be understood as the epistemology of systems theory. Human cognition in everyday activities and scientific practice does not represent an objective, given world but, instead, resembles an active process of inventing reality (Watzlawick 1984) by drawing analytical distinctions. There is no correspondence between an outer world and its 'representation' or construction in our brains (Maturana and Varela 1987). The brain operates according to structures and criteria the purpose of which is not to represent the world correctly. The only relevant criterion is viability, understood as the capacity to cope successfully with the world. As a consequence, the cognition process itself undergoes historical development and differentiation processes in response to previous cognition 
and experience. Whatever is recognized as real, relevant and true has an impact back on the cognition process itself, and vice versa. Cognitive structures and content are mutually dependent; this phenomenon is called 'self-referentiality'. On the basis of such an understanding, information and knowledge are not regarded as given entities but as the processes of informing and knowing.

What we identify as 'reality' or 'knowledge' is an ongoing contingent process of enactment (Weick 1979). Constructivism is thus understood as 'operative epistemology' (von Foerster 1981): any information is 'a difference which makes a difference' (Bateson 1972: 315). This anti-realist ontological conceptualization challenges traditional ideas of reality and knowledge. Whereas so-called radical constructivism (Glasersfeld 1995; Watzlawick 1984) focuses on processes of cognitive constructions, in systemic constructivism these processes of reality construction occur in communicative systems (Luhmann 1986; 1996). In this perspective, instances of communication are the basic elements of social systems. What is considered real, relevant and true is continuously co-created in communication. From a systems theory perspective, cognitive (individual) systems and communicative systems work independently (operationally closed). Any data are processed according to the (cognitive or communicative) structures that have evolved. Organizational phenomena cannot be ascribed directly to individual activities. Cognitive and communicative systems operate in structural coupling, however: they both process meaning and enact structures. Thoughts and communications need to be mutually connective, so that ongoing sensemaking is possible. Systemic constructivism thus strives to explain the social not from individuals' mental structures but by conceptualizing the social as an autonomous, communicative domain (Luhmann 1996; Seidl 2007).

Systemic constructivism addresses some of the open issues in the research programme of social construction (see above). In particular, systemic constructivism makes a distinction between cognitive and social systems, not taking individual agency or social 'entities' as the basis for studying social phenomena but the ongoing processes of communication (concern 1). This leads to a decentralization of agency, which implies that research relies on communication itself that has always already taken place and that creates 'reality', irrespective of individual consciousness (concern 3). Accordingly, one focus lies on the processes of drawing distinctions as the fundamental premise for shaping social 'reality' and the organization of 'knowledge' (concern 2). This allows for internalizing the difficulties associated with many unquestioned dichotomies in the social sciences. As a consequence, systemic constructivism is inherently reflexive. It emphasizes the necessity of observing the process of observation as the essence of research (concern 4). Therefore, systemic constructivism is an operative epistemology insofar as there is never a final description of a phenomenon, since knowledge creation is inherently processual and open for future development.

The fundamental shift in systemic epistemology lies in its focus on communication. One main difference from other constructivist epistemologies lies in the conceptualization of situated activities, which are reduced to manifestations and actualizations of communication. Thereby, some issues and problems of this perspective have been raised over time: while most social theories explicitly take the everyday theorizing of the social actors as an important informant about social meaning, systemic constructivism neglects individual consciousness as not being important for the study of communication or social reality; furthermore, the process of making distinctions assumes the possibility of rather clear-cut distinctions, while it can be argued that most empirical phenomena and social references are characterized by inherent ambiguity and fuzziness (Latour 1999).

\section{The empirical programme of constructivism}

By contrast to the first two constructivist versions explored here, the empirical programme of constructivism argues that it is problematic to preassume any theory of construction. The study of construction processes should not be subject to pre-conceptualized assumption but, rather, analysed empirically (Latour 2005). The creation of 'reality', the 'world' and 'knowledge' is studied as 
the product of heterogeneous, situated and fragile activities (Knorr Cetina 1989). The research process is not primarily guided by theoretical premises, which tend to 'black-box' what would actually require explicit description and explanation. The empirical programme develops a specific repertoire of research devices and methodological practices guiding the empirical research process in all its openness, messiness and fragility (Law 2004). By doing so, the empirical programme is looking for the self-evident that is taken for granted and must be deconstructed by the research process, opening the black boxes of socalled social 'reality' (Latour 1999; 2005). As a consequence, this research programme is interested in studying the inherently controversial, heterogeneous, fragile nature of social phenomena.

This explains the prominent status of the sciences in this research programme. Scientific research as the locus of knowledge creation is a prototypical context for understanding the construction of 'true', 'objective', 'valid', 'natural' worldviews in modern societies (Knorr Cetina 2002; Latour and Woolgar 1986). Furthermore, this line of research is closely related to the socalled 'practice turn' in the social sciences (Bourdieu 1977; Foucault 1971; Schatzki, Knorr Cetina and von Savigny 2001). Both are interested in understanding how the 'stability' and 'objectivity' of 'reality' is created in mundane activities, situated actions and local practices. Finally, this explains the relation of this research programme to anthropological perspectives (Geertz 1973), which cultivate the creation of an alienated view on the self-evident. Neither pre-specified theories, as in systemic constructivism, nor everyday theories of the actors involved, as in the research programme of social construction, can guide the research process, but they must be empirically reconstructed and described in their creation (Latour 2005). The main preoccupation of research is thus to develop methodologies as research practices that allow us to study 'world creation' (Knorr Cetina 1989) as the continuous 'manufacturing' of knowledge under conditions of uncertainty (Knorr Cetina 2002).

This reconceptualization of research provides several insights: the empirical programme of constructivism not only challenges unquestioned dichotomies in the social sciences, but any foundations that are taken for granted (concern 4). This is relevant for the study of 'reality', 'knowledge' and 'fact', which cannot be taken for granted, but must be described in their creation (concern 1). In parallel, it is relevant for the study of 'agency', which cannot be seen as inherent to any 'individual' or 'organization', but must be seen as resulting from inscriptions and enacted networks (concern 3). As a consequence, this research programme always reflects epistemological issues, including the status of (scientific) 'knowledge' and the idiosyncratic procedures of (scientific) knowledge creation (concern 2). The research programme propagates an understanding of research practice that is concerned with the world 'as it could be' (Law 2004; Lury and Wakeford 2012), instead of focusing on the world 'as it is'. The criterion for 'good' research is the creation of unconventional, new worldviews and perspectives (Knorr Cetina 1989), which requires 'discovery technologies', not theories.

This perspective is related to multiple approaches that came about as part of the practice turn (Schatzki, Knorr Cetina and von Savigny 2001). Among others, it resonates with grounded theory-building (Strauss and Corbin 1990) and related pragmatist epistemologies (Joas 1992), emphasizing the creative nature of action and research (Joas 1992; Tsoukas and Knudsen 2002). Moreover, it is in line with the approaches of social practice (Foucault 1971; Bourdieu and Wacquant 1992), emphasizing the importance of reflecting the practice of doing research, shifting the focus from social theories to methodological issues (Latour 2005). For example, the empirical programme insists on 'symmetry' regarding the importance of objects, actors and actions as central for 'good' research (Knorr Cetina 1989), as well as on the 'relational' aspect of knowledge creation (Law 2004). It implies that what it explores in terms of the creation of 'reality' and the 'world' also holds for scientific research itself. It also implies that - while the other constructivist epistemologies argue for particular theoretical perspectives - the empirical programme of constructivism focuses on the heterogeneity and variety of situated 
mechanisms and idiosyncratic activities, relevant for the construction and stabilization of 'reality' in particular contexts (Knorr Cetina 1989; Law 2004).

\section{Implications for strategy-as-practice research}

We now turn to recent contributions and discussions of the strategy-as-practice research programme, as seen in the light of a constructivist paradigm. The discussion follows the 'disciplinary matrix' of the constructivist paradigm (Kuhn 1974). The matrix includes issue such as the perspective from which something is explained, the kind of questions that are asked and the modes of explanations identified as particularly promising and attractive by the research programme. As in the case of a laboratory experiment, the disciplinary matrix contours the possibilities and limitations of the knowledge that can be generated within the action spaces it delineates. In our understanding, the instantiation of the constructivist paradigm takes place in four dimensions.

Dimension 1. One important starting point for strategy-as-practice research is set out by saying that the social scene consists of 'practices, practitioners, and praxis', on the basis of which strategy-making, strategy processes and strategic outcomes can be described, interpreted and explained in new ways (Jarzabkowski, Balogun and Seidl 2007). This introduces an ontological convention. It defines the 'building blocks' and taken-for-granted 'constituents' that researchers accept as given for explaining particular phenomena, activities and processes (Rheinberger and Hagner 1997; Knorr Cetina 1989).

Dimension 2. Furthermore (and this is particularly central to a constructivist paradigm), there are epistemological questions implied by studying strategy, understood as types of knowledge (Elkana 1986) and modes of knowing (Tsoukas 2005; Grand and Ackeret 2012) implied in strategy-making. This implies the question of whether strategy can be seen as a predefined academic concept (Chandler 1990), a multifaceted construction process (Mantere and Vaara 2008) or an ex-post ascription of a certain pattern of actions that lead to a certain outcome (Mintzberg 1978).

Dimension 3. Moreover, addressing ontological and epistemological issues in this perspective also has consequences for the methodological dimension: it enables research to gain insights into strategy-making, strategy processes and the dynamic mechanisms of strategic outcomes affecting those who practise strategy every day as their profession (Schütz 1932), not least beyond the insights generated by established research areas within strategy research (Johnson, Melin and Whittington 2003). In the perspective of a constructivist paradigm, this addresses the issue of research methods as 'discovery technologies' (Knorr Cetina 1989).

Dimension 4. Finally, any research programme, particularly if viewed from a constructivist perspective, asks the 'normative question': why is it important and relevant to research strategymaking in organizations by focusing on strategy as practice? In which way does such research generate novel or relevant knowledge for practice, impact on practice or even contribute to a better world? The normative question is more important than sometimes assumed, because it shapes the kind of research interests, discourses and types of presentations that will be accepted in a particular research programme.

\section{Focusing on practice: ontological issues}

\section{Practice as constructed, yet taken-for-granted reality}

Strategy as practice studies how strategy is produced, stabilized and changed in organizations through 'practices, practitioners, and praxis' (Jarzabkowski, Balogun and Seidl 2007). This focus implies a particular ontology as well as 'ontological politics' (Mol 1999), defining what is seen as existing and thus constituting the taken-forgranted, unquestioned reality, while at the same time questioning the taken-for-grantedness of other 'things' (Latour 2005) such as 'strategy', 'process' 
or 'performance' that is characteristic for alternative ontologies in strategy research. Constructivist paradigms are characterized by explicitly addressing such ontological issues, refocusing scientific research from 'describing reality' to an exploration of 'reality construction' through scientific research and social practice (Knorr Cetina 1989; Schatzki, Knorr Cetina and von Savigny 2001): there is no unbiased correspondence between the 'reality out there' and our systems of representation. At the same time, it is essential to understand the importance of 'elements' that are taken for granted in any construction process. Social constructivism suggests a pragmatic approach: "It will be enough, for our purposes, to define "reality" as a quality appertaining to phenomena that we recognize as having a being independent of our volition (we cannot "wish them away"), and to define "knowledge" as the certainty that phenomena are real and that they possess specific characteristics' (Berger and Luckmann 1967: 13, cited by Eberle 1992). Practices, practitioners and praxis can be understood as such realities within the strategy-as-practice research programme.

\section{From activities to practices in context}

A fundamental shift that comes with the SAP programme is the focus on social practices: how they are created, mobilized, actualized and changed in the everyday micro-activities of managers engaged in strategy-making (Johnson, Melin and Whittington 2003; Whittington 1996), and how activities become socially accepted patterns of action (Feldman and Orlikowski 2011; Vaara and Whittington 2012). The main inroad consists in opening the 'black box' of strategy as created in heterogeneous strategizing activities, instead of relying on takenfor-granted pre-conceptualizations of what strategy is and how strategy is made (Mintzberg 1971; 2009). The focus is on understanding the production of particular strategies through distributed activities and the mobilization of related practices (Johnson, Melin and Whittington 2003), which is not covered by existing strategy research (Johnson, Melin and Whittington 2003; Samra-Fredericks 2003; Whittington 1996). Furthermore, it is important to understand that practices are understood as socially accepted, functional heuristics on how to decide and act. Practices are only necessary regarding recurrent, important issues. This is what constitutes the distinction from an ordinary activity (Knoblauch 2005; Orlikowski and Yates 1994). Eventually, these practices are so obvious that they are unquestioned and start to represent the objectified context for members of a community: '[S]ocial reality is practices' (Taylor 1985, cited by Schatzki 2005: 470). The routinized and collectively held repertoires of practices of an organization thus represent the most relevant context for strategymaking (Endrissat and von Arx 2013). This is an object of interest very close to the empirical programme of constructivism, arguing ex ante that every managerial activity and social interaction of people within and outside an organization can potentially lead to an idea, opportunity or initiative that can gain strategic importance.

\section{From a single actor to dispersed agency and power}

Understanding strategy creation from a constructivist perspective also implies that the empirical focus must be extended beyond the interaction of top management teams in formal settings dedicated to strategy. Middle managers (Balogun and Johnson 2004; Floyd and Lane 2000; Westley 1990) and specialized strategists (Grant 2003; Pettigrew 1985, Rouleau 2005), line managers and specialized units (Ahrens and Chapman 2007; Brown and Eisenhardt 1997; Orlikowski 2002), external stakeholders, including customers (Christensen and Bower 1996), investors (Bower and Gilbert 2005), strategic partners (Dyer and Singh 1998), technology partners (von Hippel and von Krogh 2003) and consultants are involved in strategymaking. A constructivist research approach abstains from any 'great man' concept of strategy-making. Instead, constructivism in particular treats everything as a continuously generated effect of a web of relations. Nothing has reality outside the enactment of these relations. There is no stable prime mover, but there is enactment and there is performance through a multitude of actors, practices and other actants, who enact together a more or less precarious reality (Law 2008). This implies that agency does not come automatically from practices and routines 
(Feldman and Pentland 2003), heterogeneous actors or artefacts but, instead, lies in their 'embeddedness' in the network. It is these 'collective' qualities that make them 'strategic', on account of their relation to 'how an organization moves forward' (Rumelt 2011). In strategy-aspractice research, such concepts as recursiveness (Jarzabkowski 2004), styles of engagement (Chia and MacKay 2007) and leadership practices (Denis, Lamothe and Langley 2001) attempt to incorporate this relational aspect into the conceptualization of agency in strategy-making.

\section{Practices as related to tools and artefacts}

The multiple strategy tools, with artefacts involved, as well as the strategizing methods mobilized in an organization, are, on the one hand, an expression of multiple ways of systematizing strategizing activities, in addition to expressing strategic practices. The same holds for the multiple conceptual frameworks, models and tools in strategy research, which are an expression of different ways of conceptualizing such activities and practices. On the other hand, they can differ in their degree of 'generality', 'objectivity' and 'self-evidence', thus influencing the extent to which they gain their own agency (Latour and Woolgar 1986; Orlikowski 2000) and become relevant actants in the strategy-making process (Latour 2005). Routinization processes transform the usage of concepts and the enactment of particular patterns of action into stable structures and tangible references, which are used by the managers and researchers involved. From the perspective of a constructivist research programme, studying strategy-making suggests explicitly describing and reflecting the various construction technologies implied (Knorr Cetina 1989) that managers and researchers use to establish and maintain, but also to advance and change, particular strategy concepts and strategizing practices.

The strategy-as-practice research programme successfully complements strategy research by opening the black box of strategy-making. Constructivist research paradigms challenge the selfevidence of such processes, emphasizing the ontological issues implied by the identification of primary starting points for such descriptions, as well as exploring how they shape our understanding of strategy-making. Thereby, constructivist paradigms have emphasized the importance of considering a multitude of heterogeneous activities, actors, tools and artefacts involved in strategymaking. Furthermore, they insist on the importance of understanding the creation, actualization and transformation processes involved in the generation of stabilized action patterns as repertoires of practices.

\section{Framing strategy in relation to practice: epistemological issues}

\section{Double hermeneutic in conceptualizing strategy}

SAP research emphasizes the importance of explicitly considering the multitude of strategy concepts that are enacted in practice. This raises epistemological issues concerning the status of different concepts of strategy, as well as the knowledge base involved in their description, interpretation and conceptualization. A 'double hermeneutic' is implied in the conceptualization of any social phenomenon (Giddens 1987), including 'strategy'. Scientific research is seen as studying a world that is already interpreted by the social actors involved in the constitution of this reality. Out of this 'firstorder' knowledge, research produces 'secondorder' descriptions, concepts and models. Scientific and practical knowledge creation on strategy and strategy-related issues can thus benefit from this interplay between first-order and second-order concepts. It leads to an ongoing actualization, revision and transformation of such concepts within and in between academic and practical approaches to strategy. Constructivist paradigms emphasize this mechanism as an important source of understanding, viewing practitioners themselves as researchers on the social fabric of strategy, mobilizing similar methods as social scientists (Schütz 1967 [1932]).

The implications for the strategy-as-practice research stream are twofold. First, as we build on first-order knowledge, it is useful to foster new forms of collaborative and dialogical research methodologies to learn from the practitioner's knowledge (Grand 2003). Second, strategy concepts are always historically bound and context-dependent 
phenomena that are in a constant state of becoming, depending on the productiveness of the exchange between praxis and academia (Tsoukas and Chia 2002).

\section{Strategy concepts as constituted in interactions}

SAP research thus emphasizes the situatedness of strategizing activities (Johnson, Melin and Whittington 2003) and strategy creation (Tsoukas and Chia 2002). Strategy-making takes place in concrete communicative interactions; it emerges from and gains relevance and significance in specific contexts, and it must be interpreted in the perspective of these contexts. Hence, words and ideas, concepts and terms, including concepts of 'strategy', cannot be understood independently of the language games, communicative interactions and sensemaking processes in which they are produced and actualized (Seidl 2007). This implies that similar activities have different meanings according to the contexts in which they occur, as well as depending on the particular perspectives of the actors involved (Engström and Blackler 2005; Samra-Fredericks 2003; Suchman 1987). The definition of what 'strategy' means must be seen to be processual (Van de Ven 1993). Often, parallel worlds of a strategy discourse exist. One world is more aligned with the expectations implied in strategy textbooks and known strategy concepts (Porter 1985). And there is a living world of strategymaking, which is messy, implicit and embodied. Hence, the standardized concepts of strategy and the locally embedded and embodied concepts of strategy are intertwined within a singular practice or practitioner. This raises the epistemological issue of how academic research is able to reconstruct an 'objective picture' of strategy-making in practice when it is exactly the academic output that holds as a best-practice benchmark in organizations.

\section{Strategy in the face of multiple uncertainties}

'Strategy' is often conceptualized as crucial for organizational agency in future-oriented, fundamentally uncertain, contested or open situations (Schendel and Hitt 2007). It is in these situations that it is challenging, but important, to build and stabilize strategy concepts and strategizing practices as taken for granted and self-evident (Gomez and Jones 2000). Binding concepts of performance, established repertoires of methods and unquestioned issues are central for productive, coordinated strategy-making under conditions of uncertainty and ambiguity, but also for strategy research itself. In this perspective, strategy-making itself can be understood as an epistemological practice (Spender 1996; Tsoukas 1996; 2005). Such justified concepts are necessary to conclude otherwise endless scientific and managerial discussions about the appropriate conceptualization of 'strategy' and infinite regresses of defining such references as 'performance'. Accordingly, it is essential to distinguish between three sources of uncertainty (Gomez and Jones 2000; Karpik 2010; Grand 2015): uncertainty due to the impossibility of knowing the future ('Knightian uncertainty': Gomez and Jones 2000), due to the impossibility of overseeing distributed activities and processes ('Keynesian uncertainty': Gomez and Jones 2000) or due to the contingency of valuation ('Karpikian uncertainty': Karpik 2010). Strategy-making and strategy research in the face of these uncertainties are thus at one and the same time difficult (systemic constructivism would argue: it is impossible) and particularly important (systemic constructivism would argue: it is necessary).

\section{Stabilizing strategy concepts in practice}

The enactment of formalized strategy concepts is changing across situations and over time, and it must therefore be (re)created, actualized and confirmed in each situation. Strategy-as-practice research studies the heterogeneity of concepts and practices, and the reduction and extension of this heterogeneity, as central approaches to reduce uncertainty (Grand and Ackeret 2012). Talking about strategy-making and strategizing practices cannot automatically imply that they are 'stable'. From a constructivist perspective, they must, rather, be seen as 'stabilized', emerging through multiple, dispersed processes of institutionalization, socialization and routinization (Vaara and Whittington 2012; Berger and Luckmann 1967). To transcend the contingency of decisions and actions, managers use strategy concepts that are stabilized and anchored as self-evident and 
unquestionable. In this context, the practice turn provides important insights, conceptualizing construction and stabilization as discourse formation (Foucault 1978), language games (Wittgenstein 1967 [1951]), circulating references (Latour 1999), translation (Callon 1986), black-boxing (Latour 2005), materialization (Orlikowski 2000; 2002) or routinization (Gomez and Jones 2000). Dispersed strategy-related activities are coordinated in the organization because of the formation of shared expectations and 'objectivized' interpretations. Tools and methods become recognized as self-evidently relevant for strategy-making (Bower and Gilbert 2007). Practice communities not only actualize routines of strategy-making but also construct their identity as those who make strategy (Brown and Duguid 2001). The notion of 'porte parole' stresses that the ability to construct reality depends on such positions of power (Bourdieu 1982). They condense repertoires of strategymaking in the form of taken-for-granted templates, 'normal' ways of representation, visualizations and documentations (Orlikowski 2000; 2002).

A constructivist research programme brings the contingency of 'strategy', as well as the uncertainty and ambiguity of related concepts of performance, to the centre of research (Gomez and Jones 2000; Karpik 2010). As a result, strategic management as an academic discipline, scholarly field and managerial practice has an impact on the stabilization and destabilization of particular definitions within particular organizations and scientific and managerial communities alike. The impact of heterogeneous actors, activities and artefacts on such stabilization or destabilization, and thus on the confirmation or deconstruction of established power structures, is identified by the empirical programme of constructivism as essential for any in-depth understanding of these processes (Callon 1986; Latour 2005). The dynamic interaction and reflexive relationship between the construction of strategy in managerial practice and the construction of strategy in strategy research between situated, subjective concepts of strategy and generalized, objectivizing conceptualizations is a central precondition for conducting strategy research (Tsoukas 2005; Rüegg-Stürm and Grand 2014).
Research as practice: methodological issues

\section{Empirical research as questioning and pre-assuming stabilized concepts}

The decisive activities in shaping the strategy of an organization can only be identified ex post (Bower 1970; Burgelman 1994; Johnson 1987; Mintzberg and McHugh 1985; Pettigrew 1987). While research in the area of strategic management in most cases pre-assumes that it is clear what 'strategic' means, however, the SAP research programme emphasizes the need to empirically follow, describe, understand and reflect the ongoing construction of what 'strategic' means (Latour 1999; Callon 1986: Langley 1989). This implies that the concept of 'strategy' is so central, but at the same time not self-evident, that it must be explicitly reflected, conceptualized and defined in any strategy research project. Paradoxically, strategy-making under uncertainty requires that taken-for-granted strategy concepts and strategizing practices have to be stabilized as given, knowing that they are contingent and potentially questionable. This is in line with a constructivist research programme, which focuses on the dynamic interplay of confirming and transforming such concepts and practices. The 'practice turn' in the social sciences emphasizes promising perspectives here, including the concepts of routines as routinization (Feldman 2003), habitus as the embodied repertoire of practices that define whether someone is part of a particular community (Bourdieu 1977), structuration as the continuous confirmation and adaptation of action patterns (Giddens 1984), black-boxing as the activities and artefacts that translate and transform situated ideas into stable references (Latour 1999), conventions as a way of understanding the constructive but unquestioned nature of the references (Boltanski and Thévenot 1991; Gomez and Jones 2000) and common knowledge that results from the collective objectivation and typification of embedded experiences and situated interactions (Berger and Luckmann 1967; Wenger 1998). Exploring the creation of 'strategy concepts' and their situated enactment becomes a focus in itself (Tsoukas and Knudsen 2002; Vaara and Whittington 2012). 


\section{Empirical research as generating novel descriptions, interpretations, and explanations}

Constructivist paradigms have a particular view on the generative qualities of scientific research: Research not only discusses the world 'as it is' but reflects the contingency of 'reality' and 'knowledge' as it is, which leads to an interest in identifying, exploring and describing possible worlds 'as they could be' (Latour 2005; Chia and Holt 2009), or even in changing the world 'as it is' (Hacking 1999). This implies that it is essential for research to explicitly consider the inherent uncertainty and openness of any social interaction and future development as crucial (Gomez and Jones 2000). As a consequence, research itself must be seen as constructing 'reality' and 'knowledge', emphasizing the creativity and self-reflexivity of research. In particular, this includes a conceptualization of strategy-making and strategy research from the perspective of the creativity of action (Joas 1992), situated action (Suchman 1987) or interpretative flexibility (Callon 1986). Strategy-as-practice research considers this creativity in strategymaking and the distinctive forms of how this happens in practice fields (Tsoukas and Knudsen 2002). Such creative reinvention of strategy practices explains why taken-for-granted references and practices transform themselves across situations and over time (Joas 1992). Stories and repertoires, tools and artefacts referring to strategy are never unambiguous. They have to be reinterpreted and recreated in any given new situation. The same holds for the mobilization of research methods as inventive methods (Lury and Wakeford 2012).

From the perspective of constructivist paradigms, research methods have the role of enabling the study of the creation and construction, as well as the deconstruction and transformation, of important black boxes such as 'strategies' or 'strategizing' activities. Furthermore, strategy research must be seen as creative and generative itself, not focusing primarily on descriptions, interpretations or explanations of the world 'as it is' but on opening up for new perspectives, alternative interpretations and novel explanations, in the sense of construction technologies (Knorr Cetina 1989) as well as inventive methods (Lury and Wakeford
2012). In this way, the constructivist paradigms introduced above differ in their approaches to the generative quality of research. The research programme of social construction builds on the inherent creativity of social action itself, exploring 'strategy-making' as a generative practice, and thus as a source for novel insights into alternative approaches to strategy. Systemic constructivism sees its conceptual contributions as triggers for establishing novel perspectives on strategy. Finally, the empirical programme of constructivism challenges the taken-for-granted nature of many concepts in strategizing activities and in strategy research, at the same time exploring their necessity and contingency.

\section{Reflecting practical relevance: normative issues}

An underlying ambition of the strategy-as-practice research programme has always been to develop results that are of 'practical relevance' (Splitter and Seidl 2011). By doing so, the programme implicitly assumes that such relevance results directly or indirectly from explicitly considering the praxis involved in strategy-making (Johnson et al. 2007). At the same time, it is exactly this ambition that is still seen as unfulfilled by most researchers who have been working from the perspective of the SAP research programme so far (Vaara and Whittington 2012). Constructivist epistemologies allow the identification of some specific issues and challenges implied in the attempt to claim 'practical relevance'. If the world is seen as 'constructed', as it is argued in constructivist epistemologies, this implies that 'it could be otherwise'. Obviously, this awareness of contingency is a methodological issue, but it can also be seen as the starting point for changing the world as it is, and thus as a pragmatic and normative stance, in various degrees of engagement (Hacking 1999).

This is of importance for the issue of the 'practical relevance', as it identifies different types of relevance (Grand 2003). Four types of engagement are particularly interesting (as discussed by Hacking 1999).

First, a constructivist perspective can be conceptualized as a methodology emphasizing the 
construction mechanisms underlying particular phenomena. The value of an 'analytical' engagement (Foucault 1971) lies in reconstructing phenomena as they are and identifying alternatives of how they could be. Emphasizing such alternatives is a very implicit and indirect way of identifying potentially critical aspects of a current strategic practice or an established theoretical conceptualization. It can be a reference for more explicitly exploring how and why these alternatives have not emerged so far, however, for example because they have not been supported by established power structures (Guba and Lincoln 1994), have been purposefully neglected (Elkana 1986) or are discursively marginalized (Foucault 1971).

Second, this can lead to an 'ironic' engagement, which means that the contingency of a phenomenon is taken as a starting point for ironically discussing positions that accept phenomena as 'real' or 'objective' (Rorty 1989). To address such topics ironically implies a distant mode of commenting, framing and criticizing, however, without necessarily proposing alternative perspectives or practices. It remains for others in strategy research and strategic management to take up such criticism and turn it into actual changes in the strategy concepts and strategizing practices used in research projects or mobilized in organizations, and thus to develop alternative views, possibilities and opportunities.

Third, based on a normative valuation of a phenomenon, this can lead to a 'reformist' engagement, in which the fact that something could be otherwise is used to criticize the phenomenon as it is (Hacking 1999: 40); it is here that we can see the transition towards a practical engagement (Dahrendorf 2005; Elkana 1986). Here, critique turns into correction, the initial understanding of what critique is for: to correct what is currently present into something better (Walzer 1988).We can think of many different ways in which strategy research and strategic management can jointly engage in such reformist engagements: through joint research projects generating new descriptions, interpretations and explanations; through many different modes of executive education (Mintzberg 2009); and through innovation and development partnerships between academia and practice (Rüegg-Stürm and Grand 2014).
Fourth, this can lead to a 'transformative' engagement, which opts for fundamental change in the conceptualization and practice of strategymaking as the only possibility of changing and transforming the phenomenon and praxis as it is. Especially in recent attempts to rethink strategymaking from a philosophical perspective, for example on the basis of process ontology (Chia and Holt 2009), reflexive epistemology (Spender 1996; Tsoukas 2005) or inventive methods (Law 2004; Lury and Wakeford 2012), we see various suggestions for rethinking how strategy research is understood and realized, as well as how it reshapes strategic management (Vaara and Whittington 2012). Such perspectives explicitly or implicitly mobilize the normative, political and ideological critique implied in many practice theories and epistemologies (Foucault 1971; Bourdieu and Wacquant 1992; Schatzki, Knorr Cetina and von Savigny 2001; Thévenot 2006; Latour 2005).

These degrees of constructivist engagement are an inherent aspect of a constructivist paradigm and its realization in the strategy-as-practice research programme. Throughout its development as a research programme, it has not only focused on describing the practice of strategy making, as well as reflecting research practice in relation to strategy making, but explored alternative ways and future possibilities of making strategy (Mantere and Vaara 2008; Whittington 2007).

\section{Conclusion}

A constructivist research programme in strategy research implies the development of alienating perspectives as they are established and changed in strategy research and strategizing practice. Although constructivist epistemologies differ in their premises, they thus share a scepticism about anything that is simply taken for granted, selfevident or unquestioned (Hacking 1999). At the same time, more recent perspectives in these epistemologies share an emphasis on understanding better how taken-for-granted, self-evident, unquestioned references, concepts and practices for robust managerial action and scientific research are emerging, are enacted and are established, given 
the fundamental uncertainty and ambiguity implied (Gomez and Jones 2000). From the perspective of constructivist epistemologies, it would be of particular importance to transcend some fundamental opposition that underlies the distinction between strategy as practice as a new research programme and strategy research as it is understood in dominant academic and managerial discourses (Johnson et al. 2007). In particular, five points are important.

Strategy research should emphasize the importance of constantly unpacking and deconstructing fundamental, taken-for-granted concepts in strategy research and strategic management. Opening the black boxes and disassembling and reassembling strategy (Latour 2005) can be identified as a primary focus. Obviously, this focus is ambiguous, as the pre-assumption of unquestioned black boxes is a precondition for establishing a research programme. It is this ambiguity of relying on and at the same time deconstructing strategy-related black boxes that ensures the dynamism and creativity of this research programme, however.

In order to be able to disassemble the black box 'strategy' and strategy-related black boxes, it is important to cultivate alienating perspectives (Latour 2005). One common pattern of constructivist epistemologies is exactly this alienating effect, which is often criticized for its usage of abstract terminology (Luhmann 2002; Latour 2005). This is central to these research programmes, however, because they explicitly do not build on common sense or everyday theorizing concerning central concepts and terms. They introduce concepts and terms that have to gain meaning through their translation in particular contexts and specific situations (Latour 1999). This leads to an ongoing reflection and reconstruction of concepts and terms in research practice.

It is exactly the insistence on alienating perspectives that, at the same time, creates a precondition for being able to consider particularities, contexts and idiosyncrasies in empirical research. A related approach in empirical research is the attempt to exclude any theoretical perspective and concept from the initial entry into the field (Glaser and Strauss 1967). Obviously, both extremes - alienation through abstraction and alienation through the absence of abstract notions - are impossible to realize in research practice (Latour 1999). To take them as references leads to a continuous reflection of the premises and black boxes, however, which is important for any research programme in the perspective of constructivist epistemologies (Law 2004).

This reflection of research indicates that research is creation and construction. Whereas traditional epistemologies discuss the inherent creativity of research as a problem, which must therefore be disciplined through particular methodological tools, constructivist epistemologies would, on the contrary, insist on the central importance of creativity for (good) research (Joas 1992). In this line of thought, the empirical programme of constructivism explicitly emphasizes the importance of understanding methodology as 'discovery technologies' (Knorr Cetina 1989). Research methodologies are understood as enabling, ensuring and fostering creativity in research practice (as it is discussed in the science studies; see Knorr Cetina 2002).

If research is interpreted as creation and construction, it needs to be enabled by particular methodologies, technologies and practices of creation or construction (Knorr Cetina 1989). This implies that any closure of a research programme, any predefinition of central concepts and terms or any unquestioned foundation of research on one particular theory must be understood as relying on black boxes (Latour 1999). As discussed above, such black boxes are necessary for research practice, but they are also always inherently problematic at the same time (Elkana 1986); they are an expression of a particular thought style and thought community (Fleck 1980) that result from particular creation and construction processes.

From the perspective of constructivist paradigms, strategy research would focus especially on the creation and construction, routinization and stabilization, translation and transformation of strategy concepts and strategizing practices. In this respect, it is important to study the selfevident, unquestioned qualities of such concepts and practices at the same time, as well as their situatedness, idiosyncrasy and contingency. Strategies and strategizing practices are objects that strategy research and strategic management cannot assume as given, and neither are they only 
contingent. Strategies and strategizing practices are the result of continuous scientific and practical (re) construction processes, through the creative activities of the organizational actors and strategy researchers involved, and through interactions between organizational actors and strategy researchers. Specifically, constructivist paradigms suggest that SAP research should focus on advancing strategy research and the practice of strategic management, by exploring the situated construction of strategy concepts and strategizing practices, the importance of explicitly considering the uncertainty implied in strategizing, the importance of routinization processes for the establishment of strategy concepts and strategizing practices in specific organizational contexts, and the deconstruction of such concepts and practices, as it takes place in any process of translation and transformation.

\section{References}

Ahrens, T., and Chapman, C. S. (2007), 'Management accounting as practice', Accounting, Organizations and Society, 32/1: 1-27.

Balogun, J., and Johnson, G. (2004), 'Organizational restructuring and middle manager sensemaking', Academy of Management Journal, 47/4: 523-49.

Bateson, G. (1972), Steps to an Ecology of Mind: Collected Essays in Anthropology, Psychiatry, Evolution, and Epistemology. University of Chicago Press.

Berger, P. L., and Luckmann, T. (1967), The Social Construction of Reality: A Treatise in the Sociology of Knowledge. London: Penguin Books.

Boltanski, L., and Thévenot, L. (1991), De la justification: Les économies de la grandeur. Paris: Éditions Gallimard.

Bourdieu, P. (1977), Outline of a Theory of Practice. Cambridge University Press.

(1982), Ce que parler veut dire. Paris: Fayard.

Bourdieu, P., and Wacquant, L. (1992), An Invitation to Reflexive Sociology. University of Chicago Press.

Bower, J. L. (1970), Managing the Resource Allocation Process: A Study of Corporate Planning and Investment. Cambridge, MA: Harvard Business School Press.

Bower, J. L., and Gilbert, C. G. (2005), From Resource Allocation to Strategy. Oxford University Press.
Bower, J. L., and Gilbert, C. G. (2007), 'How managers' everyday decisions create or destroy your company's strategy', Harvard Business Review, 85/2: 72-9.

Brown, J. S., and Duguid, P. (2001), 'Knowledge and organization: a social-practice perspective', Organization Science, 12/2: 198-213.

Brown, S. L., and Eisenhardt, K. M. (1997), 'The art of continuous change: linking complexity theory and time-paced evolution in relentlessly shifting organizations', Administrative Science Quarterly, 42/1: 1-34.

Burgelman, R. A. (1994), 'Fading memories: a process theory of strategic business exit in dynamic environments', Administrative Science Quarterly, 39/1: 24-56.

Callon, M. (1986), 'Some elements of a sociology of translation: domestication of the scallops and the fishermen of St Brieuc Bay', in Law, J. (ed.), Power, Action and Belief: A New Sociology of Knowledge?: 196-223. London: Routledge \& Kegan Paul.

Chandler, A. D. (1990), Strategy and Structure: Chapters in the History of the American Industrial Enterprise. Cambridge, MA: MIT Press.

Chia, R., and Holt, R. (2009), Strategy without Design: The Silent Efficacy of Indirect Action. Cambridge University Press.

Chia, R., and MacKay, B. (2007), 'Post-processual challenges for the emerging strategy-as-practice perspective: discovering strategy in the logic of practice', Human Relations, 60/1: 217-42.

Christensen, C. M., and Bower, J. L. (1996), 'Customer power, strategic investment, and the failure of leading firms', Strategic Management Journal, 17/3: 197-218.

Dahrendorf, R. (2005), Engagierte Beobachter: Die Intellektuellen und die Versuchungen der Zeit. Vienna: Passagen Verlag.

Denis, J.-L., Lamothe, L., and Langley, A. (2001), 'The dynamics of collective leadership and strategic change in pluralistic organizations', Academy of Management Journal, 44/4: 809-37.

Dyer, J. H., and Singh, H. (1998), 'The relational view: cooperative strategy and sources of interorganizational competitive advantage', Academy of Management Review, 23/4: 660-79.

Eberle, T. (1992), 'A new paradigm for the sociology of knowledge: "the social construction of reality" after 25 years', Schweizerische Zeitschrift für Soziologie, 18/2: 493-502. 
Elkana, Y. (1986), Anthropologie der Erkenntnis. Frankfurt: Suhrkamp Verlag.

Endrissat, N., and von Arx, W. (2013), 'Leadership practices and context: two sides of the same coin', Leadership, 9/2: 278-304.

Engström, V., and Blackler, F. (2005), 'On the life of the object', Organization, 12/3: 307-30.

Feldman, M. S. (2003), 'A performative perspective on stability and change in organizational routines', Industrial and Corporate Change, 12/4:727-52.

Feldman, M. S., and Orlikowski, W. J. (2011), 'Theorizing practice and practicing theory', Organization Science, 22/5: 1240-53.

Feldman, M. S., and Pentland, B. T. (2003), 'Reconceptualizing organizational routines as a source of flexibility and change', Administrative Science Quarterly, 48/1: 94-118.

Fleck, L. (1980), Entstehung und Entwicklung einer wissenschaftlichen Tatsache: Einführung in die Lehre vom Denkstil und Denkkollektiv. Frankfurt: Suhrkamp Verlag.

Floyd, S. W., and Lane, P. J. (2000), 'Strategizing throughout the organization: managing role conflict in strategic renewal', Academy of Management Review, 25/1: 145-75.

Foucault, M. (1971), Die Ordnung der Dinge: Eine Archäologie der Humanwissenschaften. Frankfurt: Suhrkamp Verlag.

(1978), The History of Sexuality, vol. I, An Introduction. New York: Random House.

Geertz, C. (1973), The Interpretation of Cultures: Selected Essays. New York: Basic Books.

Giddens, A. (1984), The Constitution of Society. Cambridge: Polity.

(1987), Social Theory and Modern Sociology. Cambridge: Polity.

Glaser, B. G., and Strauss, A. (1967), The Discovery of Grounded Theory: Strategies for Qualitative Research. Chicago: Aldine.

Glasersfeld, V. (1995), Radical Constructivism: A Way of Knowing and Learning. London: Falmer Press.

Golsorkhi, D., Rouleau, L., Seidl, D., and Vaara, E. (eds.) (2010), Cambridge Handbook of Strategy as Practice. Cambridge University Press.

Gomez, P.-Y., and Jones, B. C. (2000), 'Conventions: an interpretation of deep structure in organizations', Organization Science, 11/6: 696-708.

Goodman, N. (1987), Ways of Worldmaking. Indianapolis: Hackett.

Grand, S. (2003), 'Praxisrelevanz versus Praxisbezug der Forschung in der Managementforschung', Die Betriebswirtschaft, 63/5: 599-604.
(2012), 'Routines, strategies and management: engaging for recurrent creation "at the edge", Habilitation manuscript. University of St Gallen, Switzerland.

Grand, S., and Ackeret, A. (2012), 'Managing knowledge: a process view', in Schultz, M., Maguire, S., Langley, A., and Tsoukas, H. (eds.), Constructing Identity in and around Organizations: 261-305. Oxford University Press.

Grand, S., and MacLean, D. (2007), 'Researching the practice of strategy as creative action: toward an action theoretics foundation of the research program', paper presented at the twenty-third European Group for Organizational Studies colloquium, Vienna, 7 July.

Grant, R. M. (2003), 'Strategic planning in a turbulent environment: evidence from the oil majors', Strategic Management Journal, 24/6: 491-517.

Guba, E., and Lincoln, Y. (1994), 'Competing paradigms in qualitative research', in Denzin, N., and Lincoln, Y. (eds.), Handbook of Qualitative Research: 105-17. Thousand Oaks, CA: Sage.

Hacking, I. (1999), The Social Construction of What? Cambridge, MA: Harvard University Press.

Husserl, E. (1931), Cartesianische Meditationen: Eine Einleitung in die Phänomenologie. Hamburg: Meiner.

Jarzabkowski, P. (2004), 'Strategy as practice: recursiveness, adaptation, and practices-in-use', Organization Studies, 25/1: 529-60.

Jarzabkowski, P., Balogun, J., and Seidl, D. (2007), 'Strategizing: the challenges of a practice perspective', Human Relations, 60/1: 5-27.

Jarzabkowski, P., and Spee, P. (2009), 'Strategy-aspractice: a review and future directions for the field', International Journal of Management Reviews, 11/1: 69-95.

Joas, H. (1992), Die Kreativität des Handelns. Frankfurt: Suhrkamp Verlag.

Johnson, G. (1987), Strategic Change and the Management Process. Oxford: Blackwell.

Johnson, G., Langley, A., Melin, L., and Whittington, R. (2007), The Practice of Strategy: Research Directions and Resources. Cambridge University Press.

Johnson, G., Melin, L., and Whittington, R. (2003), 'Guest editors' introduction: micro strategy and strategizing: towards an activity-based view', Journal of Management Studies, 40/1: 3-22.

Karpik, L. (2010), 'Valuing the Unique: The Economics of Singularities. Princeton University Press. 
Knights, D., and Morgan, G. (1991), 'Corporate strategy, organizations, and subjectivity: a critique', Organization Studies, 12/2: 251-73.

Knoblauch, H. (2005), Wissenssoziologie. Konstanz: UVK Verlag.

Knorr Cetina, K. (1981), The Manufacture of Knowledge: An Essay on the Constructivist and Contextual Nature of Science. Oxford: Pergamon Press.

Knorr Cetina, K. (1989), 'Spielarten des Konstruktivismus: einige Notizen und Anmerkungen', Soziale Welt, 40/1-2: 86-96.

(2002), Die Fabrikation von Erkenntnis: Zur Anthropologie der Naturwissenschaft: Erweiterte Neuaissenschaft. Frankfurt: Suhrkamp Verlag.

Kuhn, T. S. (1974), 'Second thoughts on paradigms', in Suppe, F. (ed.), The Structure of Scientific Theories: 459-82. Urbana: University of Illinois Press.

(1996), The Structure of Scientific Revolutions, 3rd edn. University of Chicago Press.

Langley, A. (1989), 'In search of rationality: the purposes behind the use of formal analysis in organizations', Administrative Science Quarterly, 34/4: 598-631.

Latour, B. (1996), 'On actor-network theory: a few clarifications plus more than a few complications', Soziale Welt, 47/4: 369-81.

(1999), Pandora's Hope: Essays on the Reality of Science Studies. Cambridge, MA: Harvard University Press.

(2005), Reassembling the Social: An Introduction to Actor-Network-Theory. Oxford University Press.

Latour, B., and Woolgar, S. (1986), Laboratory Life: The Construction of Scientific Facts, 2nd edn. Princeton University Press.

Law, J. (2004), After Method: Mess in Social Science Research. Abingdon: Routledge.

(2008), 'Actor network theory and material semiotics', in Turner, B. S. (ed.), The New Blackwell Companion to Social Theory: 141-58. Oxford: Wiley-Blackwell.

Luckmann, T. (1992), 'Social construction and after', Perspectives, 15/2: 4-5.

Luhmann, N. (1986), 'The autopoiesis of social systems', in Geyer, F., and van der Zouwen, J. (eds.), Sociocybernetic Paradoxes: Observation, Control and Evolution of Self-Steering Systems: 176-92. London: Sage.

(1996), Social Systems. Redwood City, CA: Stanford University Press.
(2002), Einführung in die Systemtheorie. Heidelberg: Carl-Auer-Systeme Verlag.

Lury, C., and Wakeford, N. (eds.) (2012), Inventive Methods: The Happening of the Social. London: Routledge.

Mantere, S., and Vaara, E. (2008), 'On the problem of participation in strategy: a critical discursive perspective', Organization Science, 19/2: 341-58.

Maturana, H., and Varela, F. (1987), The Tree of Knowledge: The Biological Roots of Human Understanding. Boston: Shambhala.

Mintzberg, H. (1971), 'Managerial work: analysis from observation', Management Science, 18/2: $97-110$.

(1978), 'Patterns in strategy formation', Management Science, 24/9: 934-48.

(2009), Managing. San Francisco: Berrett-Koehler.

Mintzberg, H., and McHugh, A. (1985), 'Strategy formation in an adhocracy', Administrative Science Quarterly, 30/2: 160-97.

Mol, A. (1999), 'Ontological politics: a word and some questions', in Law, J., and Hassard, J. (eds.), Actor Network Theory and After: 74-89. Oxford: Blackwell.

Orlikowski, W. J. (2000), 'Using technology and constituting structures: a practice lens for studying technology in organizations', Organization Science, 11/4: 404-28.

Orlikowski, W. J. (2002), 'Knowing in practice: enacting a collective capability in distributive organizing', Organization Science, 13/3: 249-73.

Orlikowski, W. J., and Yates, J. (1994), 'Genre repertoire: the structuring of communicative practices in organizations', Administrative Science Quarterly, 39/4: 541-74.

Pettigrew, A. M. (1985), The Awakening Giant: Continuity and Change in Imperial Chemical Industries. Oxford: Blackwell.

(1987), 'Context and action in the transformation of the firm', Journal of Management Studies 24/ 6: 649-70.

Porter, M. E. (1985), Competitive Advantage: Creating and Sustaining Superior Performance. New York: Free Press.

Rheinberger, H. J., and Hagner, M. (1997), 'Plädoyer für eine Wissenschaftsgeschichte des Experiments', Theory in Biosciences, 116/1: 11-32.

Rorty, R. (1989), Contingency, Irony, and Solidarity. Cambridge University Press.

Rouleau, L. (2005), 'Micro-practices of strategic sensemaking and sensegiving: how middle 
managers interpret and sell change every day', Journal of Management Studies, 42/7: 1413-41.

Rüegg-Stürm, J., and Grand, S. (2014), Das St Galler Management-Modell: 4. Generation: Einführung. Bern: Haupt.

Rumelt, R. (2011), Good Strategy Bad Strategy: The Difference and Why It Matters. New York: Crown Business.

Samra-Fredericks, D. (2003), 'Strategizing as lived experience and strategists' everyday efforts to shape strategic direction', Journal of Management Studies, 40/1: 141-74.

Schatzki, T. R. (2005), 'Peripheral vision: the sites of organizations', Organization Studies, 26/3: 465-84.

Schatzki, T. R., Knorr Cetina, K., and von Savigny, E. (eds.) (2001), The Practice Turn in Contemporary Theory. London: Routledge.

Schendel, D., and Hitt, M. A. (2007), 'Comments from the editors: introduction to volume 1', Strategic Entrepreneurship Journal, 1/1: 1-60.

Schütz, A. (1932), Der sinnhafte Aufbau der sozialen Welt. Frankfurt: Suhrkamp Verlag.

(1967 [1932]), The Phenomenology of the Social World. Evanston, IL: Northwestern University Press.

Seidl, D. (2007), 'General strategy concepts and the ecology of strategy discourses: a systemicdiscursive perspective', Organization Studies, 28/2: 197-218.

Spender, J. C. (1996), 'Making knowledge the basis of a dynamic theory of the firm', Strategic Management Journal, 17/S2: 45-62.

Splitter, V., and Seidl, D. (2011), 'Does practicebased research on strategy lead to practically relevant knowledge? Implications of a Bourdieusian perspective', Journal of Applied Behavioral Science, 47/1: 98-120.

Strauss, A., and Corbin, J. (1990), Basics of Qualitative Research: Techniques and Procedures for Developing Grounded Theory. Newbury Park, CA: Sage.

Suchman, L. (1987), Plans and Situated Actions: The Problem of Human-Machine Communication. Cambridge University Press.

Taylor, C. (1985), Philosophical Papers, vol. I, Human Agency and Language. Cambridge University Press.

Thévenot, L. (2006), L'action au pluriel: Sociologie des régimes d'engagement. Paris: Éditions $\mathrm{La}$ Découverte.
Tsoukas, H. (1996), 'The firm as a distributed knowledge system: a constructionist approach', Strategic Management Journal, 17/S2: $11-25$.

(2005), Complex Knowledge: Studies in Organizational Epistemology. Oxford University Press.

Tsoukas, H., and Chia, R. (2002), 'On organizational becoming: rethinking organizational change', Organization Science, 13/5: 567-82.

Tsoukas, H., and Knudsen, C. (2002), 'The conduct of strategy research', in Pettigrew, A. M., Thomas, H., and Whittington, R. (eds.), Handbook of Strategy and Management: 411-35. London: Sage.

Vaara, E., and Whittington, R. (2012), 'Strategy-aspractice: taking social practices seriously', Academy of Management Annals, 6/1: 285-336.

Van de Ven, A. H. (1993), 'Managing the process of organizational innovation', in Huber, G. P., and Glick, W. (eds.), Organizational Change and Redesign: Ideas and Insights for Improving Performance: 269-94. New York: Oxford University Press.

Von Foerster, H. (1981), Observing Systems. Seaside, CA: Intersystems Publications.

Von Hippel, E., and von Krogh, G. (2003), 'Open source software and the "private-collective" innovation model: issues for organization science', Organization Science, 14/2: 209-23.

Walzer, M. (1988), The Company of Critics: Social Criticism and Political Commitment in the Twentieth Century. New York: Basic Books.

Watzlawick, P. (ed.) (1984), The Invented Reality: How Do We Know What We Believe We Know? New York: W. W. Norton.

Weick, K. E. (1979), The Social Psychology of Organizing, 2nd edn. New York: McGraw-Hill.

Wenger, E. (1998), Communities of Practice: Learning, Meaning and Identity. Cambridge University Press.

Westley, F. (1990), 'Middle managers and strategy: microdynamics of inclusion', Strategic Management Journal, 11/5: 337-51.

Whittington, R. (1996), 'Strategy as practice', Long Range Planning, 29/5: 731-35.

(2007), 'Strategy practice and strategy process: family differences and the sociological eye', Organization Studies, 28/10: 1575-86.

Wittgenstein, L. (1967 [1951]), Philosophical Investigations, repr. edn. Oxford: Blackwell. 